Nat. Hazards Earth Syst. Sci. Discuss., doi:10.5194/nhess-2016-150, 2016

Manuscript under review for journal Nat. Hazards Earth Syst. Sci.

Published: 14 June 2016

(c) Author(s) 2016. CC-BY 3.0 License.

\title{
A GCMs-based mathematic model for droughts prediction in the Haihe Basin, China: Multi-GCM Divide- Integration
}

\author{
Dongmei Han ${ }^{1}$, Denghua Yan ${ }^{2}$, Xinyi Xu ${ }^{1}$, Zhongwen Yang ${ }^{1}$, Yajing $\mathrm{Lu}^{2}$ \\ $5{ }^{1}$ College of water sciences, Beijing Normal University, No. 19, XinJieKouWai St., HaiDian District, \\ Beijing 100875, P. R. China \\ ${ }^{2}$ Department of Water Resources, China Institute of Water Resources and Hydropower Research. 1-A \\ Fuxing Road, Haidian District, Beijing, 100038, P. R. China \\ Correspondence to: Denghua Yan(936282365@qq.com)
}

10 Abstract. Recently, the skilful prediction of climate change has drawn high attention from the scientific community. Evidence has been reported the skill of prediction is not satisfactory for the magnitude of inter-annual precipitation and extreme precipitation, and at a smaller spatial scale as well. Based on observational data sets and outputs from the Global Climate Models (GCMs), this study aims at achieving a mathematical model, named multi-GCM divide-integration model (MGDI). The MGDI model is developed by hybridizing finer spatial scale and multi-linear regression model (MLRM) on five state-ofart of GCMs to improve the skills of five GCMs, which is applied to the second level of water resources regionalization in China. It is found that the performance after MGDI model correction has been improved significantly over that of individual GCMs. The errors between observation and simulation after correction (1.6\% 4.4\%) are within the margin of error (smaller than 5\%) and all of the varying trends in each second level of water resources regionalization were same. Furthermore, this study also used the MGDI model to predict the variation of precipitation and droughts at different spatial scale, including second level of water resources regionalization of China and the whole HHB, for the next 40 years. Predictions indicate the climate will gradually change from drying to wetting over the HHB wherein the trend of annual rainfall is $9.3 \mathrm{~mm} / 10 \mathrm{a}$. The frequency of drought events will be decreasing as time goes on. The occurrence of mild and severe drought in the Luan River and Jidong Coastal, Tuhai majia River are higher than that in other regions, 9 and 8 respectively. These findings would provide scientific support for current water resources management and future drought-resisting planning of districts in China.

Keywords. GCMs, multi-linear regression model (MLRM), multi-GCM divided integration (MGDI), 
Nat. Hazards Earth Syst. Sci. Discuss., doi:10.5194/nhess-2016-150, 2016

Manuscript under review for journal Nat. Hazards Earth Syst. Sci.

Published: 14 June 2016

(c) Author(s) 2016. CC-BY 3.0 License.

\section{Introduction}

Under the context of global warming, variable precipitation causes all types of droughts to occur frequently, widely, continuously and simultaneously (UNISD 2009, Wang 2011, IPCC 2012), including the agricultural, meteorological and hydrological droughts. Extended meteorological droughts doubtlessly lead to hydrological droughts, which arise from both the loss of stream flow and reduction of groundwater level, and in turns to result in agricultural droughts. The severe intensity-durationfrequency droughts has threatened the sustainable development of social-economy and eco-environment, and the safety of human life in China.

In recent years, global climate models (GCMs) representing the physical processes of the atmosphere, ocean and land surface are important tools in simulating the global climate system for climate change studies (Nair et al, 2015). Topic challenges of GCMs attaching great attention by scholars are generally the skilful simulation and prediction at a smaller spatial scale (Xin et al., 2012; Chen 2013; Wang et al., 2014). Some studies usually used statistical downscaling for primary resolution of GCMs to improve accuracy, but results have generally reported that the performance of the GCMs were not satisfactory for precipitation at smaller scale over China. Also, previous studies mostly focused on using individual model or multi-model ensemble mean to assess the skills of GCMs in terms of smaller temporal and spatial scales, and corresponding results are not successful enough for prediction (Xu et al., 2010a; Wang et al., 2013; Yan et al., 2014). While plenty of efforts for many years were made, the simulation and forecastion for climate change is generally not accurate enough because of the coarse resolution of GCMs, especially for extreme precipitation in a fine scale (Gao et al., 2002; Xu et al., 2010b; Deniz et al., 2012). However, less research in China focused on the methodology and technique for improving the skill of GCMs in a view of that there had different application for individual GCM in different spatial and temporal scale (Han et al., 2015).

Following the above problems on the gap in prediction precipitation at a smaller spatial scale, this paper proposed a new method to improve the skill of GCMs at different spatial and temporal scale in consideration of the applicability of GCMs at different spatial and temporal scales. And this paper is organized as follows. We first (section 2) select the Haihe Basin, China as the study area with the 
Nat. Hazards Earth Syst. Sci. Discuss., doi:10.5194/nhess-2016-150, 2016

Manuscript under review for journal Nat. Hazards Earth Syst. Sci.

Published: 14 June 2016

(c) Author(s) 2016. CC-BY 3.0 License.

Natural Hazards

and Earth System

Sciences

Discussions

(c) (i)

characters of important strategic position of and high droughts incidence area in China. Drought index selected in this paper is standard precipitation index (SPI) because this index could calculate multi-time scale. And the correction method for statistical downscaling is MLRM based on the method of statistic. Based on results of previous studies, the paper selected firstly five GCMs from CMIP5 to evaluate their skills in the Haihe Basin, China (section 3.1). After correlation analysis for simulations and observations at different spatial scales, the secondary water resource regionalization in the HHB was selected as minimum appropriate study scale. The multi-GCM divide-integration (MGDI) model is developed by monthly MLRM calculated by monthly precipitation from five GCMs and observations in each secondary water resource regionalization of the HHB (section 3.2). After verification with the observations, the MGDI model has been further applied in predicting the precipitation (section 3.3) and droughts (section 3.4) for the period of 2011-2050. The objective of this study is to provide a novel methodology for improving skills of GCMs at a fine spatial scale, and to explore how to reduce the uncertainty inherent in GCMs. This work can provide valuable references for regional sustainable development, flood prevention and drought resistance and property security in the HHB with climate changes.

\section{Data and methods}

\subsection{Study area}

75 The study area of this research is the Haihe River Basin (HHB) in China, which is a typical region suffering extreme water shortage in China. The HHB is located between $112^{\circ} \sim 120^{\circ} \mathrm{E}$ and $35^{\circ} \sim 43^{\circ} \mathrm{N}$, including four secondary regions of water resources: Luan River and Jidong Coastal, North of Haihe, South of Haihe, and Tuhai majia River (Fig.1). Significant changes in temperature and precipitation in the HHB is the main reason of the high occurrence of droughts in recent years. As the region characterized by low annual runoff, shortage of water resources and tough contradiction between water supply and water demand, the whole environment in the HHB progressively deteriorated.

\subsection{Data sources}

The precipitation datasets used in this study are collected from two types. First, observational daily precipitation data over China are provided by the National Meteorological Information Centre (NMIC) 
Nat. Hazards Earth Syst. Sci. Discuss., doi:10.5194/nhess-2016-150, 2016

Manuscript under review for journal Nat. Hazards Earth Syst. Sci.

Published: 14 June 2016

(c) Author(s) 2016. CC-BY 3.0 License.

of China Meteorological Administration. These data are daily gridded rainfall with high-resolution $\left(0.5^{\circ} \times 0.5^{\circ}\right)$ over HHB, and have been used as observed data for the period of 1961-2010.

The other dataset used in this study is the precipitation outputs from five GCMs, including the GFDLESM2M, HADGEM2-ES, IPSL-CM5A-LR, MIROC-ESM-CHEM and NORESM1-Munder under the RCP2.6 emission scenario from the CMIP5. And the projects are divided into two periods: the simulated period (1961-2000) and the forecasted period (2011-2050). It needs to be noted that the precipitation outputs from the GCMs are downscaled and transformed into the same resolution as the observational dataset, using the methods of statistical downscaling and bilinear interpolation technique (Xu et al., 2014). In addition, the downscaled data have been further corrected by statistical error based on probability distribution function (Hagemann et al., 2011; IPS-MIP 2013; Piani et al., 2013).

In this paper, the spatial and temporal distribution of drought events were discussed. Most drought index analyse single temporal scale in some period when reflect drought conditions better. But droughts occur randomly, it is not obviously perfect enough to represent drought used some drought index with a single time scale. This paper select standard precipitation index (SPI) to analyse drought condition because of the characters of multiple time scales.

a. Standard precipitation index (SPI)

The standard precipitation index (SPI) proposed by McKee et al. (1993) and Edwards et al. (1997) is used as a drought index in this study. The SPI represents drought index on different temporal scales according to more than 30-year rainfall dataset and the formulation is simple and easy to operate.

b. Multi-linear regression model (MLRM)

Despite various improvements in statistical forecast, climate prediction still remains a challenging task. To reduce the inherent bias that always coexist with the models is inevitable. For this purpose, this study develop a mathematical model to correct biases in the GCMs outputs.

Here, as follows Eq. (1), multi-linear regression equation has been adopted using statistics correlation

Where $Y, Y^{\prime}$--dependent variable, standardized dependent variable;

$$
x_{k}, x_{k}^{\prime} \text {--argument, standardized argument; }
$$


Nat. Hazards Earth Syst. Sci. Discuss., doi:10.5194/nhess-2016-150, 2016

Manuscript under review for journal Nat. Hazards Earth Syst. Sci.

Published: 14 June 2016

(c) Author(s) 2016. CC-BY 3.0 License.

Natural Hazards

and Earth System

Sciences

Discussions

(c) $\underset{\mathrm{BY}}{(i)}$

$b_{k}, b_{k}^{\prime}$--regression coefficient, standard regression coefficient;

115

a --constant term

Because of the features and dimension of arguments, in study we have used the normalization technique to standardize, and then re-establish standardized linear regression equation, which is represent in Eq.

(2). The main method that are used to quantify the performance of the developed model are regression coefficient which can reflect the influence degree of each argument. So the standardize regression equation is shown as follow:

$Y^{\prime}=b_{1}^{\prime} x_{1}+b_{2}^{\prime} x_{2}+\ldots+b_{k}^{\prime} x_{k}$

Each of the five GCMs outputs and observational data are respectively taken as arguments and dependent variable to input for above equation. Each regression coefficient calculated from equation are adopted to correct outputs from GCMs then the feasibility of this method is verified. And the secondary region of water resources is judged as the study unit since there are higher regression coefficient through comparing different spatial scales. The MGDI model is constructed based on the method of MLRM. Thus, the future outputs are predicted using MGDI, wherein future rainfall from five GCMs are taken as inputs.

\section{Results and discussion}

\subsection{Performance of GCMs}

Based on the downscaled outputs of five GCMs for the period of 1961-2000, this study has evaluated the predicting skills of the five GCMs over HHB.

The performance of five GCMs are illustrated in Table 2. It can be inferred that the outputs of GCMs are averagely higher than observations on annual precipitation in HHB and there has less than $5 \%$ relative errors. Thus, all of the GCMs are effective in simulating the distribution of multi-year mean precipitation over HHB. The trend of inter-annual variability, which is displayed in Fig. 2, shows poor performance of these GCMs including GFDL-ESM2M, HadGEM2-ES and IPSL-CM5A-LR, and multi-model ensemble mean as well. And the magnitude of extreme precipitation shows significant degradation in the prediction of multi-model ensemble mean. 
Nat. Hazards Earth Syst. Sci. Discuss., doi:10.5194/nhess-2016-150, 2016

Manuscript under review for journal Nat. Hazards Earth Syst. Sci.

Published: 14 June 2016

(c) Author(s) 2016. CC-BY 3.0 License.

The performance of five GCMs is illustrated in Fig. 3 for multi-year mean at spatial scale. It is found that significant correlation with observed rainfall is displayed. The spatial distribution of rainfall from observation and five GCMs are "more precipitation in southeast and less in northwest" in the HHB as a whole. And the area with annual average prediction of less than $400 \mathrm{~mm}$ is smaller, as well as that of $500 \mathrm{~mm}-700 \mathrm{~mm}$.

\subsection{Correction of GCMs by monthly MGDI}

Some results can be found that the performance of five GCMs in each month at smaller spatial scales $\left(0.5^{\circ} \times 0.5^{\circ}\right.$ grid and secondary water resource regionalization) are different. Average correlation coefficient for each secondary water resources regionalization are into the range of 0.6-0.9 as a whole, but that of the grid scale are not well in correlation between simulation and observation. Hence, the outputs from five GCMs and observations could be further analysed by correlation analysis (Table 3).

Therefore, based on above correlation analysis at different spatial scales in the HHB, this study selects the secondary water resources regionalization as the finer scale. So this paper proposed the MGDI method reduce the bias inherent in GCMs at smaller scale. Monthly MGDI model is constructed to obtain different coefficients of five GCMs and then calculated the corrected outputs from MGDI model. Meanwhile, the MGDI model is used as a tool for predicting the monthly rainfall over the HHB.

The performance of MGDI model in different regions are illustrated in Fig. 4. With a view of Fig. 2, it can be inferred the performance of MGDI model has been significantly improved over that of individual

GCMs as a whole.

The performance of MGDI model in multi-year mean at the finer scale is presented in Table 4. One of the interesting thing that can be seen here is that after the correction, the skill of MGDI model increased for each secondary region of water resources. The predicted trends of MGDI model are closer to those of observations, values of which are higher than that of each GCM. It is worth mentioning that the margin of error presents a significant decrease and the uncertain projection of GCMs reduces enormously. In view of the above, the discussion yielded to important points: (1) After the correction of the GCMs outputs, namely MGDI model, the performance of prediction in each month at a smaller spatial scale of the HHB has improved significantly. So, for the better forecast, it is essential and important to correct the GCMs in most cases. (2) Developing the MGDI model, which is statistical model, is to significantly 
Nat. Hazards Earth Syst. Sci. Discuss., doi:10.5194/nhess-2016-150, 2016

Manuscript under review for journal Nat. Hazards Earth Syst. Sci.

Published: 14 June 2016

(c) Author(s) 2016. CC-BY 3.0 License.

\subsection{Forecasting precipitation for 2011-2050}

Based on the future outputs of five GCMs under the RCP2.6 emission scenario, this study adopts the MGDI model to calculate monthly precipitation over HHB and each secondary region of water resources. Annual precipitation over HHB is on the rise from 2011 to 2050 and the inter-annual variation of precipitation changes significantly. The maximum of annual precipitation will occur in 2040s (728.6mm) and it will be 1.8 times more than the minimum value. Multi-year average precipitation is $540.7 \mathrm{~mm}$ in the future 40 -year, which increase by $2.6 \%$ than that in the past 50 -year. And as decades goes on, annual precipitation will increase gradually and the tendency value reach up to $9.3 \mathrm{~mm} / 10 \mathrm{a}$ (Table 5).

It can be noted in Fig.6 that annual precipitation in every secondary region of water resources has been increasing from 2011 to 2050 as a whole, especially in Tuhai majia River wherein the slope of precipitation trend is greatest. Also, the drastic variation of annual precipitation in Tuhai majia River is more significant than those in other basins, so it's obvious that the extreme climate events might occur more frequently. After 2025, annual precipitation in south of Haihe starts to increase significantly, while the precipitation in the basins, such as Luan River and Jidong Coastal, North of Haihe, varies irregularly.

The multi-year mean precipitation in Luan River and Jidong Coastal is highest over HHB. Average annual precipitation in every secondary region of water resources reaches the highest value in 2040 that contributes much to the total precipitation of the HHB. (Table 6).

\subsection{Forecasting droughts for 2011-2050}

It is presented in Fig.7 there is an increasing tendency in annual SPI value over HHB from 2011 to 2050 Significant change of SPI value after 2025 is mainly caused by uneven distribution of precipitation. D1, D-2 droughts (D-1, D-2 represent moderate droughts and severe droughts, respectively) occur six times over HHB, in which D-2 droughts occurs twice.

Increasing slightly of the annual SPI values in each secondary region of water resources indicates that the degree of droughts reduces. Significant variation of annual SPI value symbolizes that alternate floods/droughts will occur frequently over most parts of the HHB, especially Luan River and Jidong Coastal, Tuhai majia River (Fig.8). From Table 8, it can be inferred that droughts in secondary regions of water resources occurs frequently in 2010s. The occurrence of D-1 and D-2 droughts show the values in the Luan River and Jidong Coastal, Tuhai majia River are higher than that in other regions. It is worth 
Nat. Hazards Earth Syst. Sci. Discuss., doi:10.5194/nhess-2016-150, 2016

Manuscript under review for journal Nat. Hazards Earth Syst. Sci.

Published: 14 June 2016

(c) Author(s) 2016. CC-BY 3.0 License.

mentioning that alternate floods/droughts will occur in every secondary region of water resources and the number of D-2 droughts year is increasing inevitably.

The spatial distribution of droughts is presented in Fig.9. There has been probably increasing tendency from southwest to northeast over the HHB from 2011 to 2050. Distribution of D-1 droughts is identical to those of total droughts in each secondary region of water resources. It is also seen from the distribution of D-2 droughts that the southeast region is more prone to occur than the rest of the HHB, but the difference of droughts occurrence is not obvious. The D-3 droughts, namely extreme droughts, occurs only once in North of Haihe.

The spatial distribution of droughts in all of secondary regions of water resources are various in different years. On the average, the occurrence of droughts in the northeast region is slightly higher. In 2010 s, the frequency of droughts increases gradually from western to eastern as a whole. In the next decade, in addition to the South of Haihe, the frequency of droughts presents an increasing trend from south to north. In 2030s, the spatial distribution of droughts is irregular that the frequency of droughts occurred in the southeast of the HHB is slightly less. And in 2040s, the frequency of droughts in most parts of the HHB are basically the same except that the frequency of droughts in the South of Haihe is just less than other regions once (Fig.10).

\section{Summary and conclusion}

Because of the effects on the change of climate, land use, ecological environment and other economic factors in HHB, extreme climate events (such as droughts and floods) occur with increasing frequencies in recent years. It is seen that annual precipitation decreased rapidly and the area of droughts increased over the HHB from 1961 to 2010 . The area wherein the annual precipitation was below $500 \mathrm{~mm}$ was expanding, while the area of precipitation between $600 \mathrm{~mm}$ and $800 \mathrm{~mm}$ was reduced. And the belt of annual precipitation moved southwards in recent 50 years.

With the increasing use of the GCMs, the skill of prediction has relatively improved. But at a smaller spatial scale, the accuracy of prediction decreases as the models are downscaled to higher resolution. The aim of this study is to improve the skill of GCMs in predicting the variation of precipitation and droughts and achieve a mathematical method for correcting bias in GCMs at a smaller spatial scale. 
Nat. Hazards Earth Syst. Sci. Discuss., doi:10.5194/nhess-2016-150, 2016

Manuscript under review for journal Nat. Hazards Earth Syst. Sci.

Published: 14 June 2016

(c) Author(s) 2016. CC-BY 3.0 License.

Natural Hazards

and Earth System

Sciences

Discussions

(c) (i)

It is seen that before the MGDI model is constructed, the skill of the GCMs is significantly correlated with observations for multi-year mean precipitation over HHB. But the five GCMs performance is not satisfactory in predicting the magnitude of inter-annual precipitation and extreme precipitation. After correlation analysis, the value of correlation in the secondary regions of water resources are significantly better than those in the grid level. So this study selects the secondary region of water resources as a fine spatial scale. Meanwhile, a new mathematical method, namely MGDI model is proposed, can decrease errors and improve the skill of the GCMs, significantly.

After the MGDI model, this study estimates the revolution of precipitation and droughts at the all-HHB

level and at the secondary regions of water resources level also in the next 40 years. It is found that there is an increasing tendency of annual precipitation in every secondary region of water resources and in the HHB as a whole. The forecasting of the droughts is judged using the MGDI model and it is noted that both the frequency of droughts and degrees of droughts declines in every secondary region of water resources, as the increasing precipitation in those regions contributes much to the results. Droughts occurs more frequently in the northeast of the HHB than the rest parts of the HHB, and the degrees of droughts are mainly moderate and severe. It is also found, even though the frequency of extreme droughts will reduce in the HHB as a whole, the southwest of the HHB is still the region of high-incidence droughts in the future 40 years.

\section{Acknowledgements.}

245 This work was supported by the General Program of the National Natural Science Foundation of China (Grant No. 51279207 and 51409266) and the National Key Technology R\&D Program (Grant No. 2013BAB05B04).

\section{References}

Chen HP. Prediction of extreme precipitation in China in the end of the 21st century based on CMIP5

Deniz Bozkurt, Ufuk Turuncoglu, Omer Lutfi Sen et al.. Downscaled simulations of the ECHAM5, CCSM3 and HadCM3 global models for the eastern Mediterranean-Black Sea region: evaluation of the reference period. Clim Dyn .39:207-225, 2012. 
Nat. Hazards Earth Syst. Sci. Discuss., doi:10.5194/nhess-2016-150, 2016

Manuscript under review for journal Nat. Hazards Earth Syst. Sci.

Published: 14 June 2016

(c) Author(s) 2016. CC-BY 3.0 License.

Denghua Yan, Dongmei Han, Gang Wang et al.. The evolution analysis of flood and drought in Huai

River Basin of China based on monthly precipitation characteristics. Nat Hazards. DOI 10.1007/s11069014-1109-4, 2014.

Dongmei Han, Yu Gao, Hongyang Fang et al.. Analysis on the forecast of the Regularity of droughts and floods in Northeast in the next 50 years Water resources and Hydropower engineering, 46(10):1-5, 2015. Edwards D C, Mckee T B. Characteristics of 20th Century Drought in the United States at Multiple Time

Scales. Fort Colling: Department of Atmospheric Science Colorado State University, 1997.

Hagemann S., Chen C., Haerter J. O., et al. Impact of a statistical bias correction on the projected hydrological changes obtained from three GCMs and two hydrology models. Journal of Hydrometeorology, 12(4): 556-578, 2011.

Intergovernmental Panel on Climate Change (IPCC). Managing the risks of extreme events and disasters to advance climate change adaptation, Cambridge University Press, Cambridge, UK, and New York, USA, 2012.

ISI-MIP. The Inter-sectoral Impact Model Inter-comparison Project Design and Simulation protocol (V2.3).4.30, 2013.

Gao C, Zhang ZT, Chen S et al. The high-resolution simulation of climate change model underRCP4.5 scenarios in the Huaihe River Basin. Geographical Research, 33(3):467-477, 2014.

Lin Wang, Wen Chen. A CMIP5 multi-model projection of future temperature precipitation, and climatological drought in China. Int. J. Climatol. 34: 2059-2078, 2014.

Mckee T B Doesken N J Klaist J. The relationship of drought frequency and duration to time scales. California Earth Conference on Applited Climatology, 1993.

275 Nair, Archana, Uma C. Mohanty, and Tarini C. Panda. "Improving the performance of precipitation outputs from Global Climate Models to predict monthly and seasonal rainfall over the Indian subcontinent", Comptes Rendus Geoscience, 2015.

Piani C., Weedon G. P., Best M., et al. Statistical bias correction of global simulated daily precipitation and temperature for the application of hydrological models. Journal of Hydrology, 395(3): 199-215, 2010. United Nations International Strategy for Disaster Reduction Secretariat (UNISDR), Global assessment report on disaster risk reduction. Risk and poverty in a changing climate. Invest today for a safer tomorrow, NewYork, UNISDR, 2009.

Wang XM. Climate change lead to drought. Science News, (6), 56-59, 2011. 
Nat. Hazards Earth Syst. Sci. Discuss., doi:10.5194/nhess-2016-150, 2016

Manuscript under review for journal Nat. Hazards Earth Syst. Sci.

Published: 14 June 2016

(c) Author(s) 2016. CC-BY 3.0 License.

Weiguang Wang, Quanxi Shao, Tao Yang et al.. Multi-model ensemble projections of future climate

9, 2013.

$\mathrm{Xu} \mathrm{CH}$, Luo Y, Xu Y. Assessment and projection for spatial-temporal distribution of precipitation in china based on global climate models. Advanced in Climate Change Research, 6(6):398-403, 2010a.

$\mathrm{Xu} \mathrm{CH}$, Luo Y, Xu Y. Simulation and prediction of drought variations in china by multi-model ensemble.

Journal of Glaciology and Geocryology, 32(5):867-874, 2010b.

Xin XG, Wu TW, Zhang J. CMIP5 climate system model tests carried out by BCC presentation.

Advanced in Climate Change Research, 8(5):378-382, 2012.

Xu Y, Zhou B, Zhou BT et al. Risk prediction of flood change in China based on CMIP5 models. Advanced in Climate Change Research, 10(4):268-275, 2014.

Table 1: Degree and description of droughts based on SPI value.

\begin{tabular}{ccccc}
\hline SPI & $(-\infty,-2]$ & $(-2,-1.5]$ & $(-1.5,-1]$ & $(-1,+\infty)$ \\
Degree & 3 & 2 & 1 & 0 \\
& Extreme & severe & moderate & normal \\
Description & droughts & droughts & droughts & \\
\hline
\end{tabular}

Table 2: The performance of GCMs for multi-year average precipitation over HHB during 1961-2000

\begin{tabular}{ccccccc}
\hline Indicator name & Observations & $\begin{array}{c}\text { GFDL- } \\
\text { ESM2M }\end{array}$ & $\begin{array}{c}\text { HadGEM2- } \\
\text { ES }\end{array}$ & $\begin{array}{c}\text { IPSL-CM5A- } \\
\text { LR }\end{array}$ & $\begin{array}{c}\text { MIROC- } \\
\text { ESM-CHEM }\end{array}$ & $\begin{array}{c}\text { NorES } \\
\text { M1-M }\end{array}$ \\
$\begin{array}{c}\text { Multi-year average } \\
\text { precipitation(mm) }\end{array}$ & 535.4 & 521.8 & 524.9 & 514.4 & 519.4 & 518.8 \\
Tendency(mm/10a) & -20.9 & -6.4 & -6.8 & -2.0 & 9.2 & 1.3 \\
\hline
\end{tabular}

300

Table 3: Correlation coefficient between observation and simulation of monthly precipitation in different secondary water resources regionalization during 1961-2000

\begin{tabular}{cccccc}
\hline Division & $\begin{array}{c}\text { GFDL- } \\
\text { ESM2M }\end{array}$ & $\begin{array}{c}\text { HadGEM- } \\
\text { 2ES }\end{array}$ & $\begin{array}{c}\text { IPSL-CM5A- } \\
\text { LR }\end{array}$ & $\begin{array}{c}\text { MIROC-ESM- } \\
\text { CHEM }\end{array}$ & $\begin{array}{c}\text { NorESM1- } \\
\text { M }\end{array}$ \\
$\begin{array}{ccccc}\text { Luan River and Jidong } \\
\text { Coastal }\end{array}$ & 0.81 & 0.77 & 0.81 & 0.77 & 0.83 \\
North of Haihe & 0.79 & 0.79 & 0.78 & 0.78 & 0.82 \\
South of Haihe & 0.75 & 0.73 & 0.73 & 0.74 & 0.79 \\
Tuhai majia River & 0.73 & 0.68 & 0.67 & 0.70 & 0.79 \\
\hline
\end{tabular}


Nat. Hazards Earth Syst. Sci. Discuss., doi:10.5194/nhess-2016-150, 2016

Manuscript under review for journal Nat. Hazards Earth Syst. Sci.

Published: 14 June 2016

(c) Author(s) 2016. CC-BY 3.0 License.

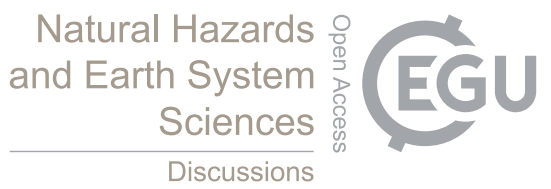

(c) (1)

Table 4: The performance of MGDI model for multi-year average precipitation in each secondary water resources regionalization during 1961-2000.

\begin{tabular}{|c|c|c|c|c|}
\hline Region & Name & Observations & Correction & error \\
\hline & $\begin{array}{c}\text { annual } \\
\text { precipitation }(\mathrm{mm})\end{array}$ & 535.4 & 519.3 & $3 \%$ \\
\hline Dasm & $\operatorname{trend}(\mathrm{mm} / 10 \mathrm{a})$ & -20.9 & -19.3 & Same trend \\
\hline $\begin{array}{l}\text { Luan River } \\
\text { and Jidong }\end{array}$ & $\begin{array}{c}\text { annual } \\
\text { precipitation(mm) }\end{array}$ & 567.5 & 555.0 & $2.2 \%$ \\
\hline Coastal & $\operatorname{trend}(\mathrm{mm} / 10 \mathrm{a})$ & -8.2 & -9.5 & Same trend \\
\hline North of & $\begin{array}{c}\text { annual } \\
\text { precipitation }(\mathrm{mm})\end{array}$ & 503.5 & 495.4 & $1.6 \%$ \\
\hline & $\operatorname{trend}(\mathrm{mm} / 10 \mathrm{a})$ & -7.4 & -9.7 & Same trend \\
\hline South of & $\begin{array}{c}\text { annual } \\
\text { precipitation(mm) }\end{array}$ & 536.8 & 533.2 & $4.4 \%$ \\
\hline & $\operatorname{trend}(\mathrm{mm} / 10 \mathrm{a})$ & -25.2 & -23.3 & Same trend \\
\hline $\begin{array}{l}\text { Tuhai } \\
\text { majia }\end{array}$ & $\begin{array}{c}\text { annual } \\
\text { precipitation }(\mathrm{mm})\end{array}$ & 576.4 & 566.1 & $1.8 \%$ \\
\hline River & $\operatorname{trend}(\mathrm{mm} / 10 \mathrm{a})$ & -35.1 & -32.5 & Same trend \\
\hline
\end{tabular}

305

Table 5: Chorological variation in terms of annual precipitation over HHB. The colour arrows indicate the level of magnitude of annual mean precipitation in each eras.

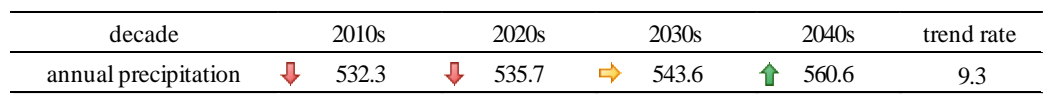

310 Table 6: Variation in annual precipitation of each secondary water resources regionalization in different eras during 2011-2050. The colour arrows indicate the level of magnitude of annual mean precipitation in each eras.

\begin{tabular}{|c|c|c|c|c|c|c|c|c|c|c|}
\hline decade & & $2010 \mathrm{~s}$ & & $2020 \mathrm{~s}$ & & 2030s & & 2040 s & trend & trend rate $(\mathrm{mm} / 10 \mathrm{a})$ \\
\hline Luan River and Jidong Coastal & & 580.6 & $\sqrt{2}$ & 585.7 & $\sqrt{2}$ & 590.3 & 个 & 611.6 & $--=\square$ & 9.8 \\
\hline North of Haihe & $\sqrt{2}$ & 525.0 & 及 & 530.7 & \& & 524.4 & 个 & 547.3 & $---\square$ & 6 \\
\hline South of Haihe & $\sqrt{2}$ & 520.2 & $\sqrt{3}$ & 515.1 & $\Rightarrow$ & 534.9 & 它 & 546.6 & $--\square \square$ & 9.9 \\
\hline Tuhai majia River & $\sqrt{2}$ & 526.0 & 个 & 560.5 & $\Rightarrow$ & 554.8 & 个 & 574.0 & $-\square=[$ & 13.8 \\
\hline
\end{tabular}


Nat. Hazards Earth Syst. Sci. Discuss., doi:10.5194/nhess-2016-150, 2016

Manuscript under review for journal Nat. Hazards Earth Syst. Sci.

Published: 14 June 2016

(c) Author(s) 2016. CC-BY 3.0 License.
Natural Hazards and Earth System

Sciences

Discussions

315 Table 7: Number of different degrees droughts for the individual eras in secondary water resources regionalization during 2011-2050.

\begin{tabular}{ccccc}
\hline $\begin{array}{c}\text { Eras and } \\
\text { Degree }\end{array}$ & $\begin{array}{c}\text { Luan River and } \\
\text { Jidong Coastal }\end{array}$ & $\begin{array}{c}\text { North of } \\
\text { Haihe }\end{array}$ & $\begin{array}{c}\text { South of } \\
\text { Haihe }\end{array}$ & $\begin{array}{c}\text { Tuhai majia } \\
\text { River }\end{array}$ \\
$2010 \mathrm{~s}$ & 3 & 2 & 1 & 4 \\
$2020 \mathrm{~s}$ & 2 & 0 & 1 & 1 \\
$2030 \mathrm{~s}$ & 2 & 2 & 3 & 1 \\
$2040 \mathrm{~s}$ & 2 & 2 & 1 & 2 \\
Droughts & 9 & 6 & 6 & 8 \\
D-1 & 7 & 3 & 4 & 5 \\
D-2 & 2 & 2 & 2 & 3 \\
D-3 & 0 & 1 & 0 & 0 \\
\hline
\end{tabular}

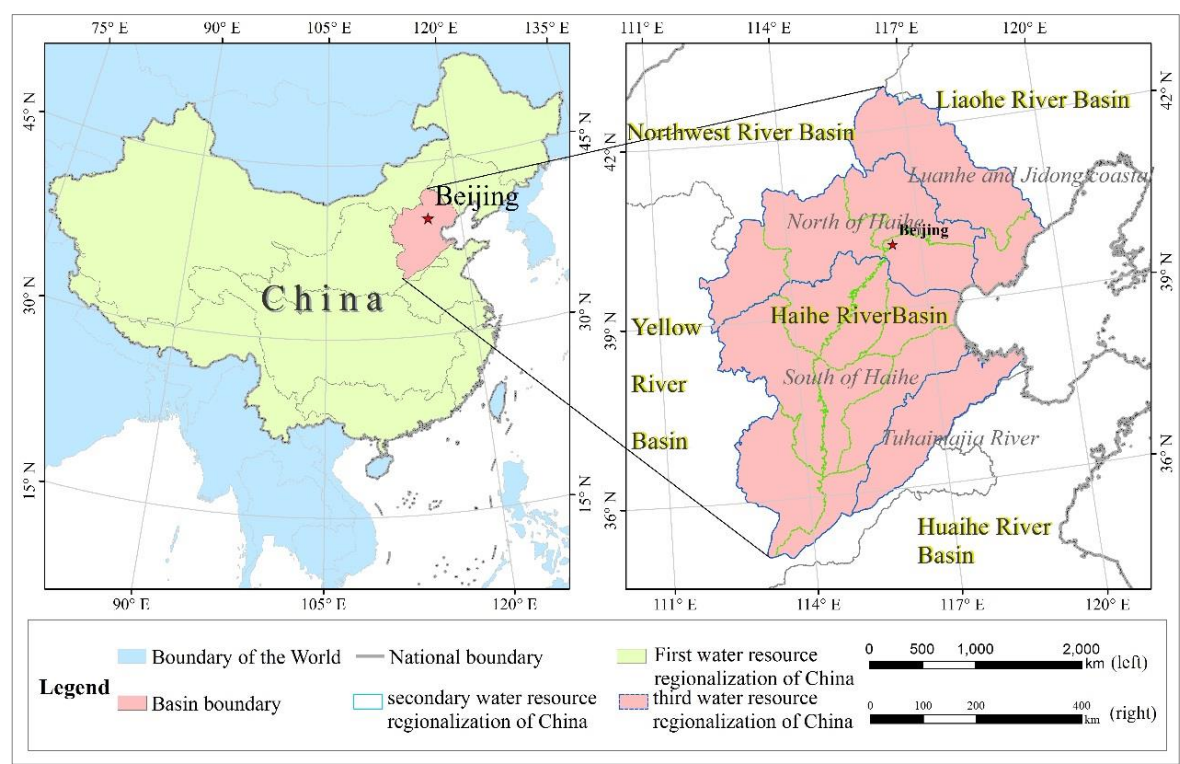


Nat. Hazards Earth Syst. Sci. Discuss., doi:10.5194/nhess-2016-150, 2016

Manuscript under review for journal Nat. Hazards Earth Syst. Sci.

Published: 14 June 2016

(c) Author(s) 2016. CC-BY 3.0 License.
Natural Hazards and Earth System Sciences

Discussions

(c) $\underset{\mathrm{BY}}{(i)}$

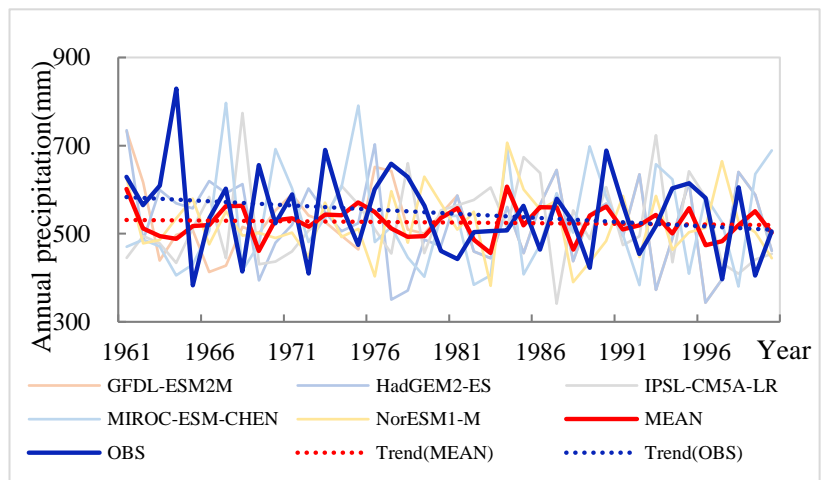

Figure 2: The performance of five GCMs and multi-model ensembles mean over HHB during 1961-2000. (The blue line represents the variation curve of observational values, the red line represents the changing curve of multi-model ensemble mean, and the blur lines represent the variation curve of the outputs from five GCMs.)

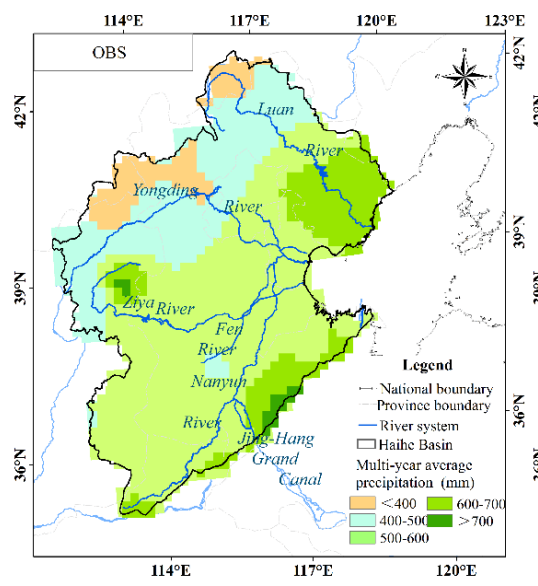

(a)

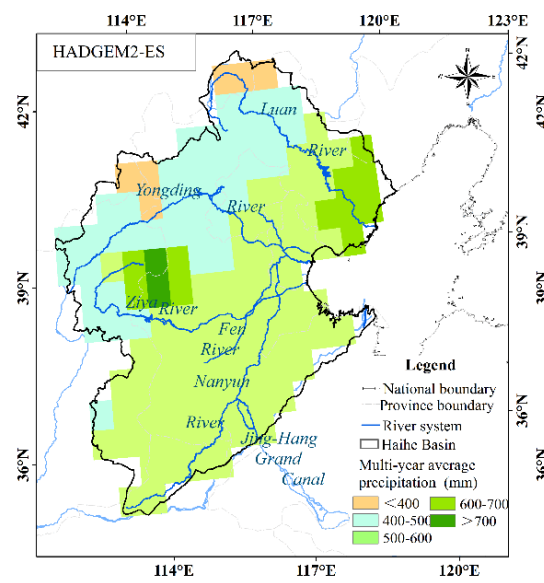

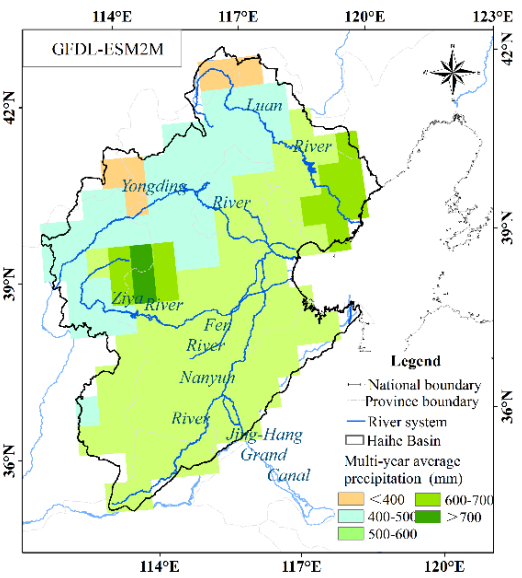

(b)

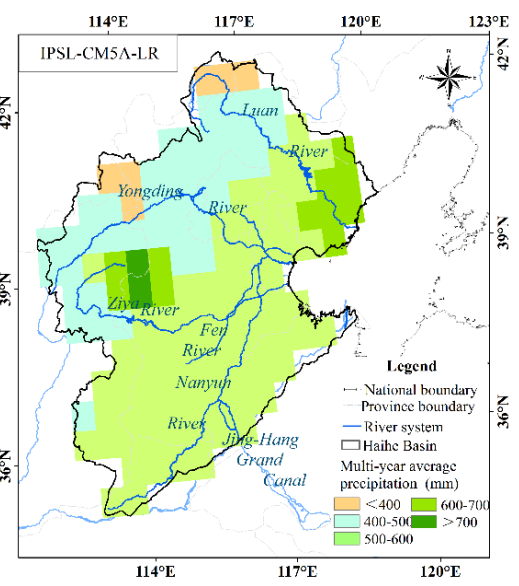


Nat. Hazards Earth Syst. Sci. Discuss., doi:10.5194/nhess-2016-150, 2016

Manuscript under review for journal Nat. Hazards Earth Syst. Sci.

Published: 14 June 2016

(c) Author(s) 2016. CC-BY 3.0 License.

\section{(c) (i)}

\section{Natural Hazards and Earth System \\ Sciences \\ Discussions}

(c)

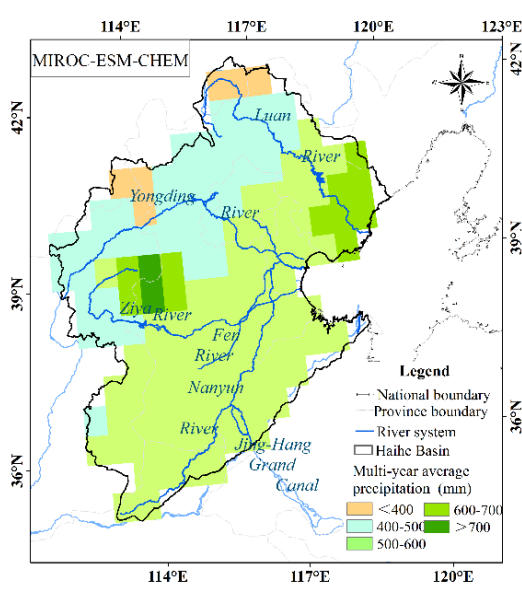

(e) (d)

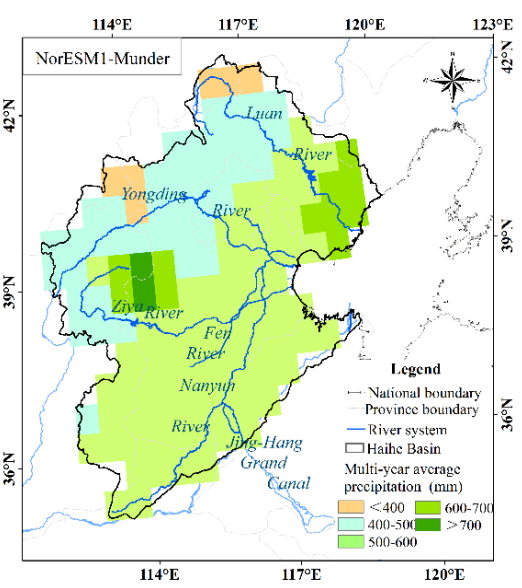

(f)

Figure 3: Comparison of spatial distribution of multi-year average precipitation between simulations from five GCMs and observations.
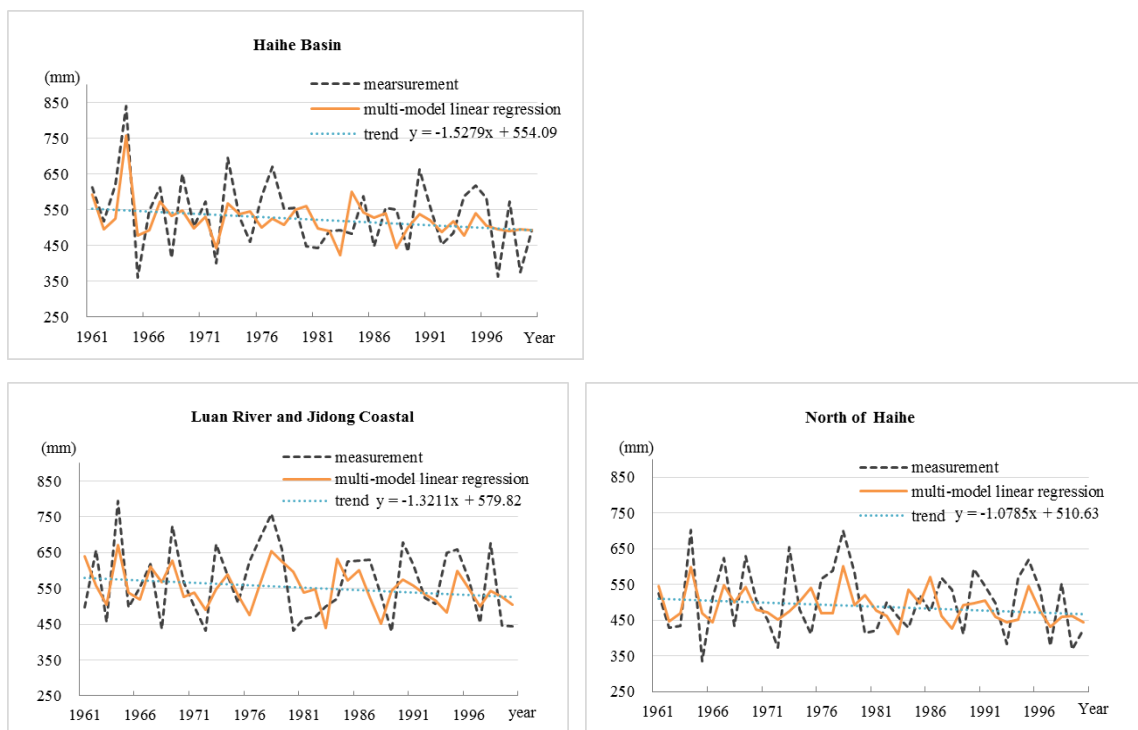
Nat. Hazards Earth Syst. Sci. Discuss., doi:10.5194/nhess-2016-150, 2016

Manuscript under review for journal Nat. Hazards Earth Syst. Sci.

Published: 14 June 2016

(c) Author(s) 2016. CC-BY 3.0 License.
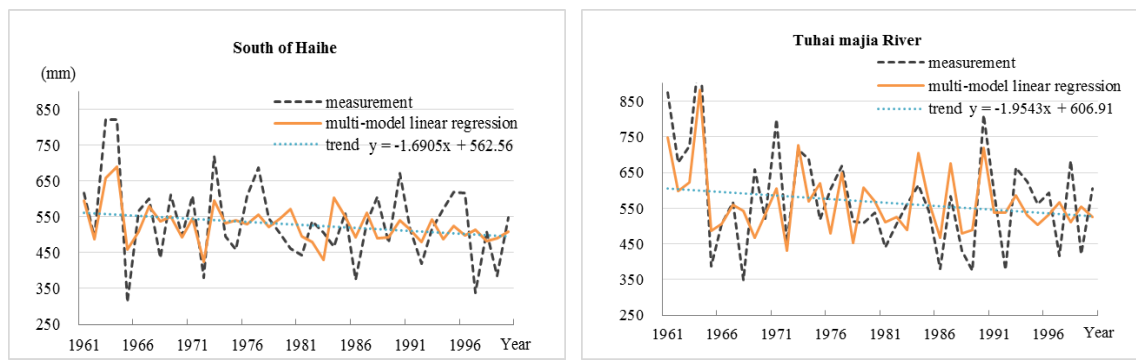

Figure 4: Comparison of measured and corrected annual precipitation in each secondary water resources

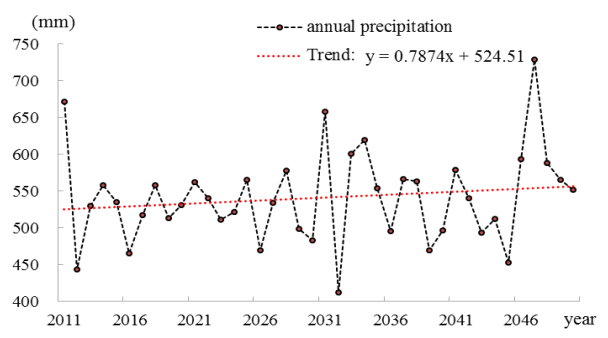

Figure 5: Inter-annual variation in terms of annual precipitation over HHB. The numbers on the y-coordinate and the $x$-coordinate indicate number of annual precipitation and years, respectively. And the red line represents the trend line of precipitation.
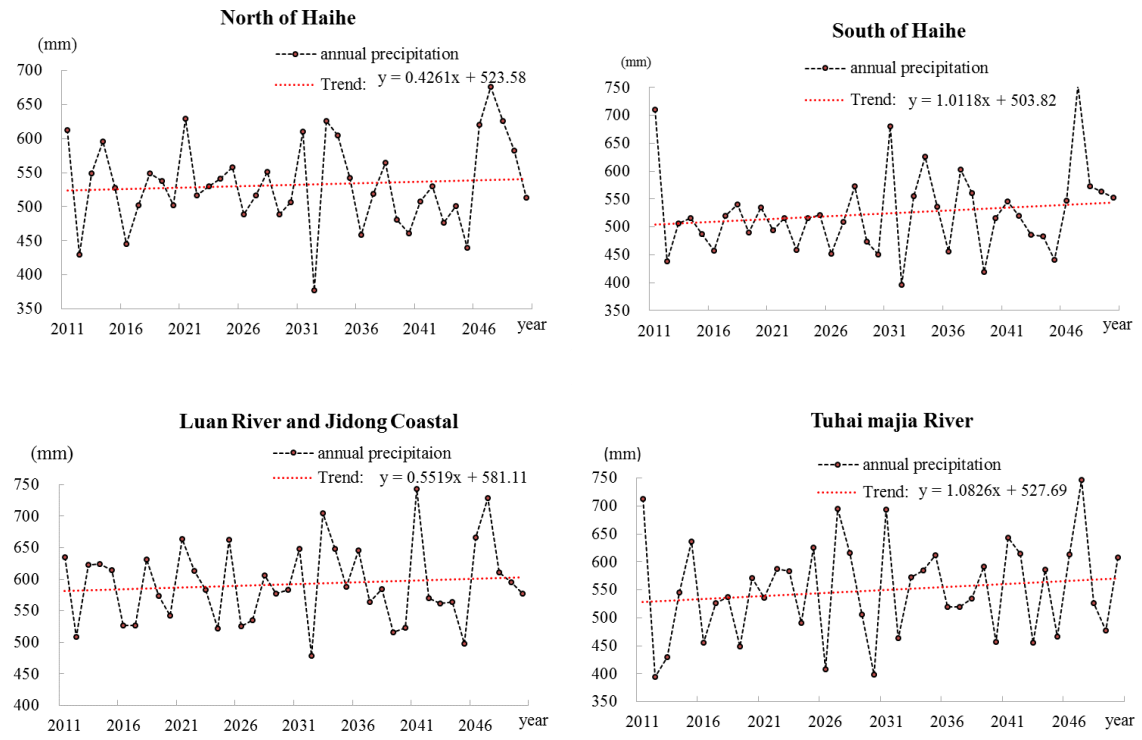
Nat. Hazards Earth Syst. Sci. Discuss., doi:10.5194/nhess-2016-150, 2016

Manuscript under review for journal Nat. Hazards Earth Syst. Sci.

Published: 14 June 2016

(c) Author(s) 2016. CC-BY 3.0 License.

Figure 6: Variation of annual precipitation in each secondary water resources regionalization during 20112050. The numbers on the $y$-coordinate and the $x$-coordinate indicate number of annual precipitation and

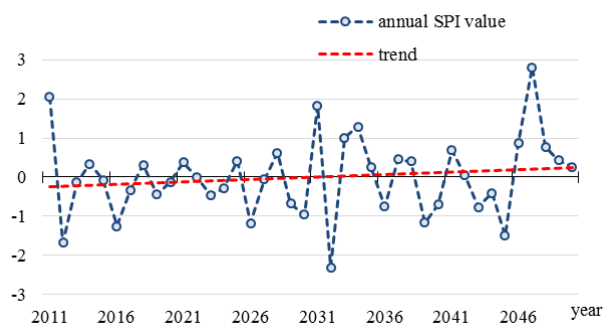

Figure 7: Variation in annual SPI values over HHB during 2011-2050. The numbers on the y-coordinate and the x-coordinate indicate degree of droughts and years, respectively. And the red line represents the trend line of SPI values.
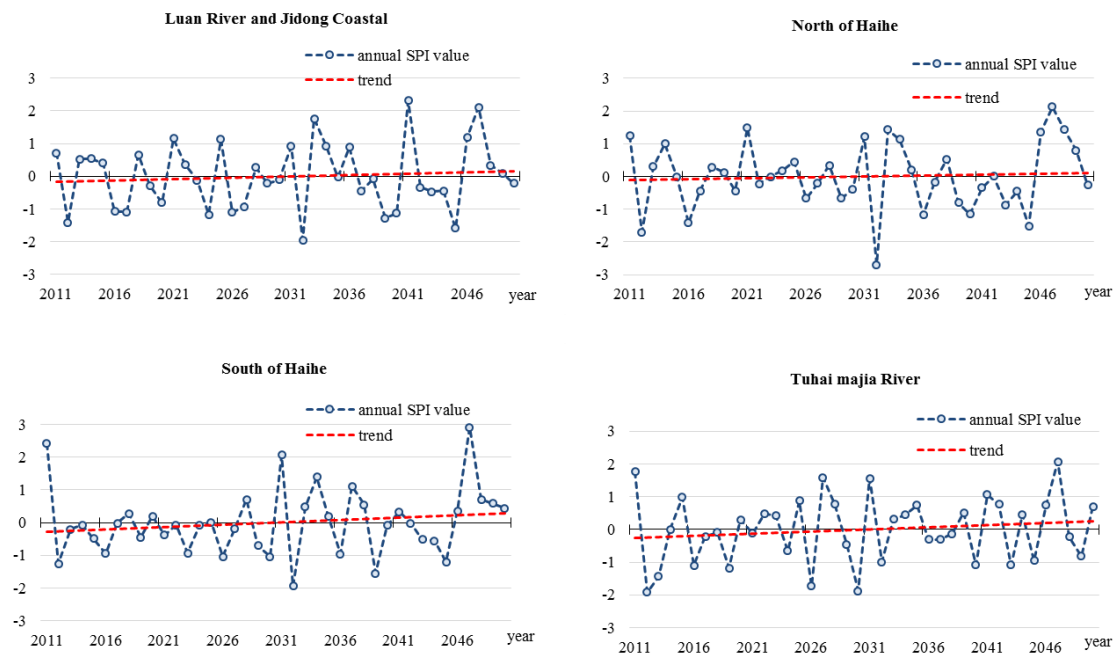

Figure 8: Variation in annual SPI values in secondary water resources regionalization of China during 20112050. 
Nat. Hazards Earth Syst. Sci. Discuss., doi:10.5194/nhess-2016-150, 2016

Manuscript under review for journal Nat. Hazards Earth Syst. Sci.

Published: 14 June 2016

(c) Author(s) 2016. CC-BY 3.0 License.

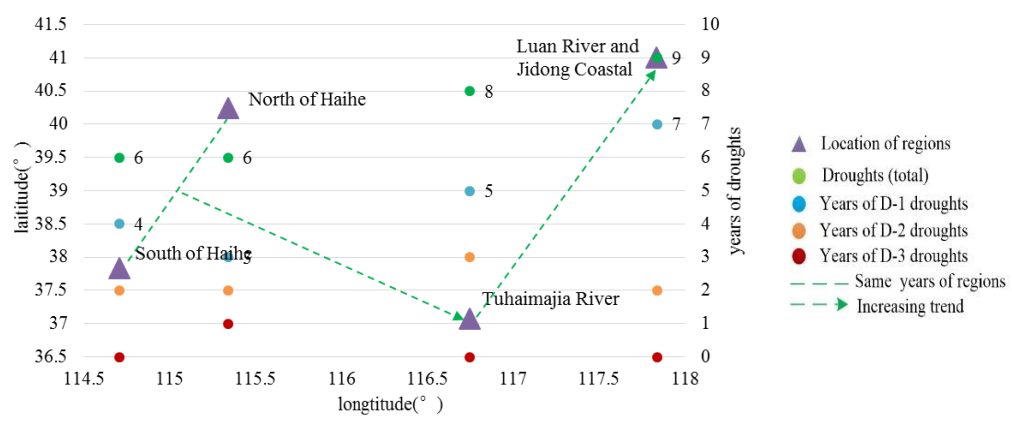

Figure 9: Spatial variation of different degrees droughts in HHB in future 40 years (The $x$-axis symbols the longitude location of regions. The left $y$-axis symbols the latitude location of regions and the right $y$-axis symbols the years of different degree droughts. The triangle corresponds to the $x$-axis and left $y$-axis and the colourful circles correspond to the $x$-axis and right $y$-axis. The green lines shows the spatial trend of total droughts.)
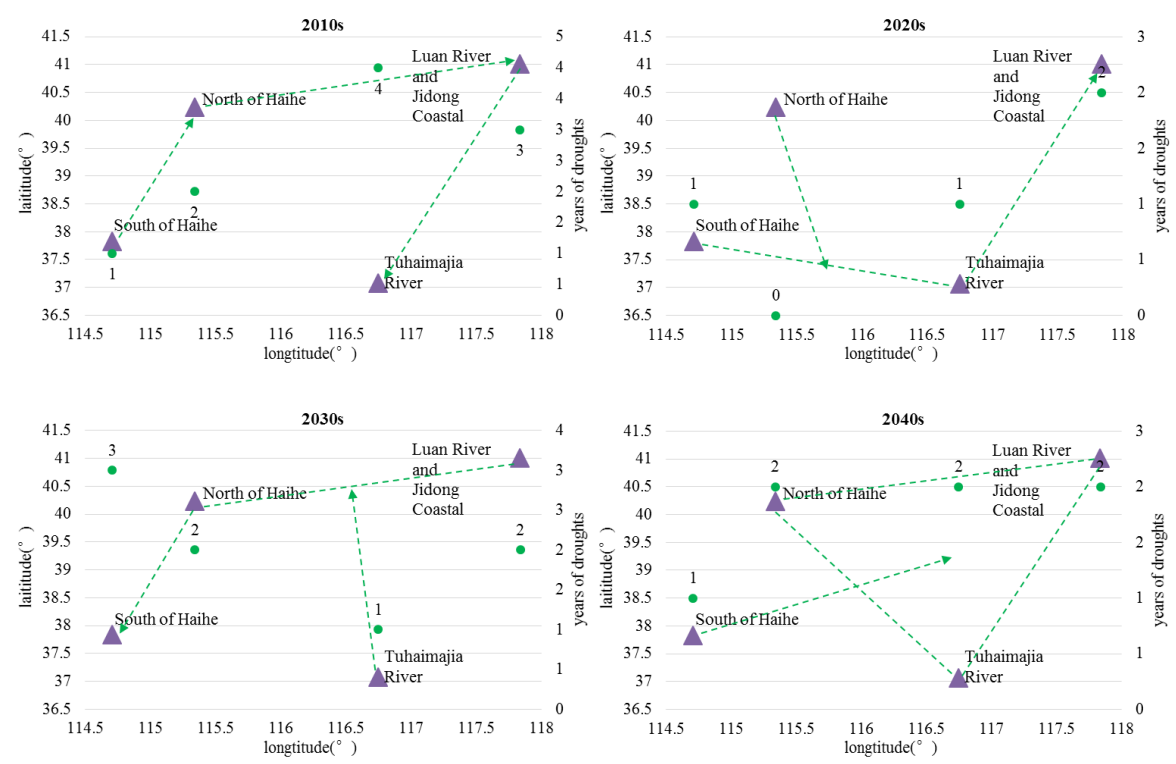

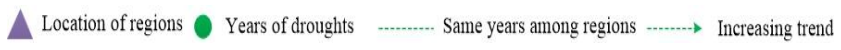

Figure 10: Spatial variation of droughts in HHB in future different eras (The $x$-axis and the left $y$-axis symbol the location of regions which correspond to triangles. And the right $y$-axis symbols years of different degree droughts which marked in colourful circles. The green lines shows the spatial trend of total droughts.) 